\title{
Sources and Contexts of Modernism in the Art of Vilnius in the Interwar Period
}

\section{Iwona Luba}

University of Warsaw

Institute of Art History

iluba@uw.edu.pl

The paper is an attempt to define the term "Vilnius modernism", its earliest manifestations in various, and even contradictory, formulas. The sources of modern art in Vilnius after the end of the Great War, artistic, historical and ideological contexts of the dynamically changing phenomenon of Vilnius modernism - from late symbolism, through neoclassicism, to strictly avant-garde art - are indicated. Both theoretical declarations/ manifestoes as well as works of art and their interpretations at that time are taken into account.

Keywords: Vilnius modernism, Vilnius Society of Visual Artists, Faculty of Fine Arts of Stephen Báthory University, First New Art Exhibition in Vilnius, historicism, avant-garde. 
It seems that there were very few manifestations of modernism in the art of Vilnius in the early 1920s, and artistic life after the Great War was only beginning to wake up and very slowly at that. Only a few events in the artistic life of Vilnius between 1919-1923 can be mentioned: 12 October 1919 - establishment of the Faculty of Fine Arts of Stephen Báthory University by Ferdynand Ruszczyc; December 1920 - establishment of the Vilnius Society of Visual Artists (hereinafter WTAP); September 1921 - publication of the first issue of Południe (Noon) magazine 1921, published by WTAP; March 1922 - First Annual Exhibition of WTAP; April 1923 - Exhibition of works by Jewish artists; May 21, 1923 - First New Art Exhibition; 2 June 1923 - Second Annual Exhibition of WTAP. Despite the insignificant number of events, one can distinguish a few models of modernism that share interesting common relations each other.

The studies on the history of Vilnius art to date lack information about the creative activity of the two most influential figures of Vilnius at the time - painter Ferdynand Ruszczyc and photographer Jan Bułhak. This activity deserves special attention. Shortly after World War I, painter Ruszczyc, photographer Bułhak and architect Juliusz Kłos (1881-1933) propagated the Polishness of Vilnius, especially during the establishment of new Soviet-Polish-Lithuanian borders. They worked together on the album Polish Wilno. Chief Monuments of Polish National Architecture in Wilno, Once the Second Capital of Poland. The album was issued by the Polish Ministry of Foreign Affairs as propaganda material in 1921 in French and English to be distributed at a meeting of the League of Nations to support Polish claims to Vilnius (Wilno in Polish) in the context of the then-running Polish-Lithuanian conflict. The album Polish Wilno was to prove to the international community that Vilnius belonged to Poland by right.

Polish Wilno contains 40 photographic prints signed by Bułhak, glued on cards, in the form of an exquisite photographic portfolio. Bułhak was able to use light very well, giving the architectural details a monumental look. Polish Wilno is the most photographic and artistic of the albums used in peace negotiations after the First World War. The latest photographic conventions combined with a historical-artistic view of architecture present a promotional-propaganda masterpiece: 
It is important to note that the use of authoritative photographic statements to present Poland's territorial claims in the international arena and justify its ambitions for independence were not just a Polish peculiarity, but a phenomenon which accompanied the emergence of other new states in eastern and central Europe during and after the First World War. Symptomatic in this context are the wartime issues of Lart et les artistes (Art and Artists), one of the leading French academic journals devoted to art history and artistic life. ${ }^{1}$

There is not even a mention of this album in Ruszczyc's biography, which was compiled after his death by Bułhak. Another text by Bułhak is worth reading carefully: Why did Ruszczyc "stop painting". Posthumous memories with a portrait of the artist who:

He loved the dignity of architecture and city monuments desecrated in captivity, buried their glorious and tragic fates, guarded their surviving remnants, taught to learn and worship the legacy of centuries of respectable culture. $<\ldots>$ He multiplied artistic beauty $<\ldots>$ miraculously and introduced it into everyday life, into books, magazines, prints, theatre and performances, into education and universities, into homes and streets. $<\ldots>$ and he connected everything with the name of the Polish homeland. Few understood and worshipped this mission of his. ${ }^{2}$

In the context of the joint activities of Bułhak, Ruszczyc and Kłos, these words acquire a real meaning.

Ferdynand Ruszczyc, active in Vilnius since 1908, was active in the protection of the Polish cultural heritage of the city, including the art and architecture monuments during the Russian partition. These activities resulted in two events of 1912 initiated by Ruszczyc: the album Wilno z przed stu lat w akwarelach Franciszka Smuglewicza (Vilnius in watercolors by Franciszek Smuglewicz) ${ }^{3}$ and the creation of the Municipal Photographic Archive (Russian: Gorodskoy Fotograficheskiy Archiv), documenting the monuments of Vilnius. The photographer Jan Bułhak managed the archive

1 Ewa Manikowska, Photography and cultural heritage in the age of nationalisms: Europe's Eastern borderlands (1867-1945), London; New York; Oxford; New Delhi; Sydney: Bloomsbury Visual Arts, 2019, p. 179.

2 Jan Bułhak, Dlaczego Ruszczyc "przestat malować”. Wspomnienia pośmiertne z portretem artysty, Wilno: St. Turski, 1936, pp. 7-8.

3 Wilno z przed stu lat w akwarelach Franciszka Smuglewicza, [Zdobił książkę Ferdynand Ruszczyc], Wilno: Księgarnia L. Zawadzkiego, 1912. 
and took documentary photographs of the deteriorating monuments on Ruszczyc's recommendation and according to his instructions. They continued their documentary mission during the Great War.

According to Eric Hobsbawm's terminology, they are involved in "finding tradition", including "inventing tradition" and its "mass production". The phenomenon of "mass-producing traditions, common in Europe (and not only) at the turn of the 19th and 20th century, intensified before and just after the Great War in a completely new Europe, with new state bodies, borders, power structure, in a Europe looking for its new identity ${ }^{4}$. The period of World War I is a clear caesura between idioms. Earlier there was, among other things, the idea of erecting monuments adorned with allegories, which reached its apogee in 1870-1914. This idiom of symbolic discourse disappears drastically in the interwar period (hence perhaps the long-term impossibility of erecting a Mickiewicz monument in Vilnius). "'Invented traditions' have significant social and political functions and would neither come into existence nor establish themselves if they could not acquire them."

Ruszczyc and Bułhak, as the creators of Polish Wilno, used the experience of "finding traditions" gained during the Great War thanks to their cooperation with the Kunstschutzoffizieren in the service of the German army. They were Manfred Buhlmann, Paul Clemen and Paul Weber. They were dealing with the legitimacy of German rule in the occupied territories as part of a project called Kunstschutz, i.e. protection of monuments.

A model of the idiom created during the Great War appeared in Vilnius - for the purposes of war and nationalist propaganda by the countries involved in the global conflict. This idiom was affirmed and "taken over" by Ruszczyc and Bułhak - key figures in the artistic environment of Vilnius between the wars. It appeared most clearly in the "native photography" project, reproduced in an impressive number of book and press illustrations as well as photo albums and publications of a tourist guide nature. Idiom functioned very well socially and politically throughout the Second Polish Republic, and even longer. One can see here an efficiently functioning mechanism of "going out of the city" and broadening the criterion of

4 Eric Hobsbawm, “Mass-Producing Traditions: Europe, 1870-1914”, in: Eric Hobsbawm, Terence Ranger, The Invention of Tradition, Cambridge: Cambridge University Press: 1996, p. 263.

5 Ibid., p. 307. 
belonging. It is connected with Vilnius on several levels. Important for the identity of the people of Vilnius and, more broadly, for Poland, the feeling of Vilnius and Polishness, in which peaceful, somewhat provincial Vilnius began to function almost as the mother of Polishness.

The creators of this idiom themselves have been silent about its partly German origins, emphasising mainly the Vilnius Young Poland genesis - in Ruszczyc's turn-of-the-century painting in Vilnius and in the thoroughly Polish one. According to the same assurances, the pictorial native photography of Bułhak draws from the inexhaustible source of the symbolic painting imaginarium of the same Ruszczyc. Bułhak wrote about it in the album Weqdrówki fotografa w stowie i obrazie. T. VIII-IX: Pejzaż Wilna (z 32 ilustracjami autora. Wilno 1936; Wandering of the photographer in word and image. Vol. VIII-IX: Landscape of Vilnius). He emphasised the rediscovery of the old, and long forgotten spell of Vilnius - "it was fully revealed to the world by Ferdynand Ruszczyc", who, like an "apostle", "took on the hardship of a private, became the spiritual leader of the city, the uncrowned king of Vilnius' majesty. <...> He became the guardian of his spell, the bell of his eminence, he became the soul of Vilnius. After this apostolate of Ruszczyc, others have already made their task easier. It is sufficient to follow in his footsteps [...]"6.

Ruszczyc and Bułhak jointly implemented various Vilnius projects, such as Wilno i ziemia wileńska: zarys monograficzny, t. 1, Wilno, 1930 (Vilnius and Vilnius Land: a an outline of a monograph, t. 1, Vilnius, 1930), where the comments and layout of the illustrations were prepared by F. Ruszczyc. Apart from numerous photographs by Bułhak, we can find there a reproduction of Ruszczyc's drawing depicting Józef Piłsudski's entry into Vilnius ${ }^{7}$.

The sources of Bułhak's native photography were not only in Ruszczyc's "apostolic" work, which he invariably pointed to. Ewa Manikowska's book Photography and cultural heritage in the age of nationalisms: Europe's Eastern borderlands (1867-1945) highlights the strong inspirations of both artists with the German war project Kunstschutz, especially architect and art historian Manfred Bühlmann, whom they met in German-occupied

6 Jan Bułhak, Dlaczego Ruszczyc "przestat malowac", p. 8.

7 Wilno i ziemia wileńska: zarys monograficzny, t. 1., Stanisław Kościałkowski ed., Ferdynad Ruszczyc ill., Wilno: Wojewódzki Komitet Regjonalny, 1930. 
Vilnius ${ }^{8}$. In his memoirs, Bułhak considered the meeting with Bühlmann as a turning point in his life, comparable only to his friendship with Ruszczyc ${ }^{9}$. It was Bühlmann who introduced him to the idea of Heimatphotography, which lies at the source of Bułhak's "native photography".

Bühlmann came as a Kunstschutzoffizier to Vilnius, the main centre of the Gebiet des Oberbefehlshabers der gesamten deutschen Streitkräfte im Osten, as part of the Kunstschutz programme carried out in the occupied area by the German army. Richly illustrated album publications and tourist guides published under this project were to prove the indigenous German character of the area's ancient art. It was then that the term "Vilnius style" appeared for the first time. Bułhak collaborated with Kunstschutzoffizieren Bühlmann, Clemen and Weber, his photographs were reproduced in large numbers both in the books mentioned above and in the illustrated supplements to popular German magazines Zeitung der 10. Armee, Wilnaer Zeitung and Kownoer Zeitung and on postcards. During the Great War, Bułhak was a key research figure on the cultural heritage of Vilnius ${ }^{10}$. Paul Weber, Professor of Art History at the University of Jena in his publication Wilna. Eine vergessene Kunststätte, München 1917, has published many photographs taken by Bułhak ${ }^{11}$. In this book, for the first time, Vilnius is strongly referenced as a forgotten city. The same adjective was used by Bułhak in his texts about Vilnius and Ruszczyc from 1936.

Bühlmann was a great admirer of Bułhak's photography and Ruszczyc's painting. It was probably Bühlmann who persuaded Ruszczyc, according to Bułhak's account, "In 1917, in agreement with the editors of the German magazine Zeitung der X Armee, he provided materials for the issue of this magazine about the work of Ruszczyc"12.

8 Ewa Manikowska, Photography and cultural heritage; Eadem, "Mutual Influences Kunstschutz and the Shaping of Polish Art History at the Time of the First World War", in: R. Born, B. Störtkuhl (Hg.), Apologeten der Vernichtung oder "Kunstschützer"? Kunsthistoriker der Mittelmächte im Ersten Weltkrieg, Köln Weimar Wien: Böhlau Verlag, 2017, p. 83-101; Laima Laučkaite, "The Heritage of Vilnius in the Eyes of German Art Historians during World War I", in: ibid., p. 141-158. See also: Laima Laučkaitè, Vilniaus daile Didžiojo karo metais, Vilnius: Lietuvos kultūros tyrimų institutas, 2018; Algė Andriulytė, Ferdynandas Ruszczycas: Civis Vilnensis Sum, Vilnius: Vilniaus dailès akademijos leidykla, 2018.

9 Ewa Manikowska, Photography and cultural heritage, p. 157.

10 Ibid., p. 178.

11 Paul Weber, Wilna. Eine vergessene Kunststätte, München: R. Piper, 1917.

12 Jan Bułhak, "Daty biograficzne dotyczące życia i działalności Ferdynanda Ruszczyca", in: Ferdynand Ruszczyc. Życie i dzieło. Ksiega zbiorowa, kom. red. Jan Bułhak et al., Wilno: Skład Główny Księgarni św. Wojciecha, 1939, p. 438. 
Bułhak and Ruszczyc, in cooperation with the art historians from the Zeitung der X Armee circle, learned the secrets of the "finding tradition" and its "mass production", which they later applied with great success. It should be stressed here, however, that the activities of German art historians during the Great War were no exception; on the contrary, they were part of the strategies of historical policy and the use of research on art history and cultural heritage of disputed or conquered territories by various European countries.

The idiom of "tradition production" was very strong in Vilnius, not only in the photographic image but also in the word. In 1920, Ruszczyc gave a lecture on Polish architectural traditions and the cultural heritage of Vilnius. His activity in this field was not isolated, and the idiom of "Vilnius artistic tradition" was becoming increasingly common. Even the term Vilnius School of Painting appeared, and the Faculty of Fine Arts of Stephen Báthory University became a link between the old times and the present.

In December 1920, a new artistic group was established in Vilnius - Vilnius Society of Visual Artists (Wileńskie Towarzystwo Artystów Plastyków, WTAP), which mainly brought together graduates of St. Petersburg's pre-revolutionary high art schools and represented the contemporary St. Petersburg formula of European Neoclassicism. WTAP was largely made up of painters, graphic artists and architects educated in pre-revolutionary St. Petersburg, including Ludomir Sleńdziński: Felicjan Szczęsny Kowarski, Stanisław Woźnicki, Maria Borzobohata-Woźnicka, Halina Dąbrowska, Jerzy Hoppen, Kazimierz Kwiatkowski and Gustaw Pilecki. Sleńdziński knew Aleksander Yakovlev and Boris Shukhaev well, and he stayed in contact with them after his return to Vilnius. Felicjan Szczęsny Kowarski was a journeyman in their St. Luke Guild in St. Petersburg. Gustaw Pilecki as a student of the University of St. Petersburg, in 1915 started to study painting and drawing with Vasily Shukhaev and Alexander Yakovlev at the New Art Studio (Novaya Khudozhestvennaya Masterskaya).

There were more direct contacts between the St. Petersburg artistic circle and the Vilnius group. The creative manners, composition principles, iconography, canon of characters from paintings and sanguine 
drawings by the indicated St. Petersburg and Vilnius painters were often very similar. The art convention worked out by Shukhaev and Yakovlev in Dmitri Kardovsky's studio turned out to be close to other Polish artists educated in St. Petersburg as well. The inspirations of Yakovlev and Shukhaev can be found not only in the work of WTAP members, but also in other fields.

WTAP also adopted the idea of artistic education from St. Petersburg. It played an important role in the programme of the Vilnius group ${ }^{13}$. In one of the interviews, Sleńdziński emphasised the pedagogical activity of WTAP in the Drawing School, then the School of Artistic Crafts, as well as - at a higher level - in the Faculty of Fine Arts at Stephen Báthory University, connected with the aims of the group ${ }^{14}$.

In 1921, a magazine issued by WTAP began to be published in Vilnius under the meaningful title Noon, referring to the St. Petersburg magazine Apollon. Noon was the epiphany moment of the (nietzschean) Apollo. This moment was represented by graphics in both St. Petersburg and Vilnius magazines. The editorial staff of Noon announced the blossoming and fullness of Polish art (by implication - thanks to the initiative and artistic activity of Vilnius painters from Ludomir Sleńdziński's circle).

The mechanism of "inventing tradition" started to work very quickly and effectively with regard to WTAP members, and in particular with regard to Sleńdziński. In this case, there was a quite interesting process of "displacing" actual sources in favour of "producing" the local Vilnius tradition.

Władysław Tatarkiewicz gave a lecture $O$ Wileńskiej Szkole Malarstwa (On the Vilnius School of Painting) to the Vilnius Society of Friends of Science. It was published in the first issue of Noon ${ }^{15}$. Thanks to the nomination of Tatarkiewicz himself, Sleńdziński, a painter representing modern classicism from St. Petersburg, became not only a Vilnius classic, but also a master of the entire Vilnius School of Painting. It is difficult to deny the truth of the latter claim. Ludomir Sleńdziński has indeed gathered around him a group of artists imitating his way of painting and a group of students of the Faculty of Fine Arts of Stephen Báthory University in Vilnius.

13 In detail - see: Dariusz Konstantynów, Wileńskie Towarzystwo Artystów Plastyków 1920-1939, Warszawa, 2006.

14 S. Z. Kl. [Klaczyński], "O Wileńskim Towarzystwie Artystów Plastyków i jego ideologii. Z powodu 10-lecia i wystawy WTAP wywiad z prof. L. Sleńdzińskim”, in: Kurier Wileński, 11.06.1930, p. 2 .

15 Władysław Tatarkiewicz, "O Wileńskiej Szkole Malarstwa”, in: Południe, No. 1, 1921, pp. 3-18. 
Sleńdziński was quickly promoted to the rank of heir and continuator of Vilnius classicism - as "a grandson and son of old Vilnius artists". It is true that Ludomir Sleńdziński's father Wincenty and grandfather Alexander were active painters in Vilnius, but none of them represented Vilnius Classicism of the early 19th century, just as Ludomir did not continue this Classicism ${ }^{16}$. Neither did he continue the painting style of his ancestors. In Sleńdziński's works from the early 1920s, one can clearly see even direct borrowings from the works of his St. Petersburg colleagues, very expressive for example in the composition Boys Catching Fish (1922). It is "almost a repetition of Yakovlev's diploma painting from 1913 - Bathing Boys"17.

In the collective consciousness, however, Sleńdziński functioned as a Vilnius classicist, even though art critics noted and even emphasised the St. Petersburg origins of his manner of painting ${ }^{18}$.

Władysław Skoczylas aptly noted at the first Vilnius exhibition that: "[Ludomir] Sleńdzinski, as a student of the St. Petersburg academy, has those common features which link Professor Kardowski's most eminent students, whether they are Russians, like [Vasily] Shuhaev, [Boris] Grigoriev and [Alexander] Yakovleff, or Poles, like [Ludomir] Sleńdziński and [Felicjan Szczęsny] Kowarski, into a certain school ${ }^{19}$. In 1930, the Warsaw painter and art critic Wiktor Podoski, in a review of the WTAP jubilee exhibition on the occasion of its 10th anniversary, even went so far as to suggest that Vilnius neoclassicists should be called: "the St. Petersburg-Vilnius school", since "almost all members of this faction have studied at the St. Petersburg Academy (mostly with Prof. Kardowski) and this influence has been weighing on them so far" ${ }^{20}$. Critics wrote about St. Petersburg-Vilnius painting by Sleńdziński, emphasising however, more and more strongly its Vilnius character. The artists of WTAP started to be called the "Vilnius

16 Ibid., p. 18. In detail: Iwona Luba, Dialog nowoczesności z tradycją w malarstwie polskim dwudziestolecia międzywojennego, Warszawa: Wydawnictwo Neriton, 2004, pp. 136-137; Eadem, “,From the Impressionist Chaos to the World of Form and Construction' or Vasiliy Shukhaev, Aleksander Yakovlev and their Polish Epigones”, in: Vasiliy Shukhaev: Art, Biography, Heritage: A collective monograph, scientific editor E. P. Yakovleva; compilers: E. N. Kamenskaya, E. P. Yakovleva, Moscow: BooksMArt, 2019, pp. 122-139.

17 Dariusz Konstantynów, op. cit., p. 163.

18 Wiktor Podoski, "Z Zachęty. Wystawa Jubileuszowa Wileńskiego Towarzystwa Artystów Plastyków”, in: Rzeczpospolita, No. 120, 1920, p. 9; por. Dariusz Konstantynów, op. cit., p. 164.

19 Władysław Skoczylas, “Z wystawy Stowarzyszenia Wileńskich Artystów Plastyków. Sleńdziński”, in: Tygodnik Ilustrowany, No. 46, 1922, p. 737.

20 Wiktor Podoski, op. cit., p. 9; see: Dariusz Konstantynów, op. cit., p. 164. 
school" not only in Vilnius ${ }^{21}$. As one can see, the term "Vilnius school" was commonly used to refer to the Vilnius group.

Over time, Sleńdziński himself began to introduce historicising elements, props and stylisations to legitimise the dignity of the "Vilnius classic" with his art and his own self-creation. Sleńdziński also had a strong position in Vilnius. He worked as a professor of painting at the Faculty of Fine Arts of Stephen Báthory University, as well as with the main "producers of the Vilnius artistic tradition": Tatarkiewicz, Ruszczyc, Bułhak and Kłos. The latter also had experience as head of the Faculty of Architecture and Landscape Care at the Ministry of Art and Culture in $1919^{22}$. He also developed Wilno. Przewodnik krajoznawczy Juliusza Kłosa, Prof. Uniwersytetu St. Batorego, Wilno 1923 (Vilnius. Juliusz Kłos's sightseeing guide, Prof. St. Bathory University, Vilnius 1923), twice re-issued $(1929,1937)^{23}$.

Sleńdzinski and WTAP monopolised art, critics and artistic education in Vilnius, although initially there was little interest in their artistic achievements in Vilnius, and the attendance at the first exhibition of WTAP was even poor, as Adamska-Roubina, a member of WTAP, admitted in 1930: "last Sunday, the jubilee exhibition of WTAP at the post-Tyszkiewicz Palace was visited by more people than the annual exhibition of WTAP in 1922 for the entire 40 days of its opening!"24.

In the spring of 1923, the first collective exhibition of avant-garde artists in Poland, the First Exhibition of New Art, was opened in Vilnius. It was, however, an incidental event for this city. The choice of Vilnius was conditioned by the fact that repatriates from post-revolutionary Russia had arrived there a little earlier, as had the initiators and co-organisers of the exhibition: The exhibition was organised by the following artists: Witold Kajruksztis (Vytautas Kairiūkštis) and Władysław Strzemiński. Most of the participants of the exhibition: Karol Kryński, Henryk Stażewski, Mieczysław Szczuka, Teresa Żarnowerówna, however, came from Warsaw and it was there that the first strictly avant-garde group, Blok, was soon established in 1924.

21 Wileńskie Towarzystwo Artystów Plastyków 1920-1930, Wilno, 1930.

22 Dariusz Marciniec, "Ministerstwo Sztuki i Kultury Rzeczypospolitej Polskiej w latach 1918-1922”, in: Rocznik Łódzki, No. 63, 2015, p. 95.

23 Wilno. Przewodnik krajoznawczy Juliusza Kłosa, Prof. Uniwersytetu St. Batorego, Wilno: Wydawnictwo Oddziału Wileńskiego Polsk. Tow. Krajoznawczego, 1923 (1929, 1937).

24 Paleta Wilna, 2, 1930, K. Adamska-Roubina (ed.), p. 5. 
The exhibition was opened to the public in the hall of the Corso cinema (Lux cinema) at 7 Adam Mickiewicz Street, which is the main artery of Vilnius, leading to the Cathedral Square, not far away from it, i.e. in a highly visible and frequented place. The cinemas were visited by the masses. The exhibition was opened in May and June 1923, i.e. during important church feasts that brought crowds of believers to the cathedral, such as Pentecost, Holy Trinity, Corpus Christi, the latter with a procession through the city. It can be assumed, therefore, that the exhibition had a large turnout, even if this was partly accidental. The Vilnius press (and more) wrote about the exhibition.

The creators carefully prepared the ground for this event. An educational text by Witold Kajruksztis, announcing the exhibition, contains programmatic texts of the avant-garde, a commentary by Władysław Strzemiński was published in Zwrotnica (The Crossover) magazine: "The general guideline of the exhibition: the creation of a new perfection, a new classicism $\langle\ldots\rangle$ by all significantly artistic and new directions achieved (Cézanne, Cubism, Futurism, Purism, Suprematism). $<\ldots>$ It is only on the basis of all formal achievements of contemporary art that it is possible to lead and create excellent modern art" ${ }^{\prime 25}$.

The modernity of the First New Art Exhibition had many aspects. It manifested itself in the stylistics of the works, in the graphic design of the small size catalogue, which was yet striking because it presented a very avant-garde typography, unknown so far in Vilnius, in radical slogans (p. 11), in the arrangement of the exhibition and in the choice of the place itself - the modern Corso cinema (Lux cinema) in the very centre, at 7 Mickiewicza Street, near the Cathedral Square. They were also to organise their future exhibitions in places associated with modernity - for example, in car showrooms in Warsaw. The exhibition was also connected with educational activities - in its space, as well as the mentioned educational and promotional activities in the Vilnius press (before its opening - W. Kajruksztis) and the national press - in Zwrotnica ${ }^{26}$.

The objective of the First New Art Exhibition and its creators has been defined by Władysław Strzemiński as searching for a new perfection, a 1923, p. 193.

25 Władysław Strzemiński, “Wystawa Nowej Sztuki w Wilnie”, in: Zwrotnica, No. 6, 26 Ibid 
new classicism, on the basis of all creative efforts so far, i.e., with reference to tradition in its dynamic, Eliotian meaning. For tradition, as understood by Thomas Stearns Eliot subjectively, consists only of those elements of history that have the ability to actively shape the present. In his sketch Tradition and the Individual Talent from 1919, Eliot pointed out, among the features that constitute tradition, among others: full creative maturity of its recipient - the artist, aware of history and his own contemporaneity ${ }^{27}$. Eliot's turn towards tradition understood as a memory uniting the past and the present was a turn towards permanent values allowing for overcoming the chaos of the surrounding world and searching for its perfect order. It was an extremely important turn, especially for artists who, like Strzemiński, experienced the hell of the Great War, and later, like himself, Witold Kajruksztis or Kazimierz Malewicz, experienced the October Revolution and its consequences, when the promise of a new democratic order and new art turned out to be, in fact, chaos, enslavement of man and art, no less hell than the Great War.

Władysław Strzemiński, in his text $B=2$, published in 1924, preached the need to learn about tradition in depth: "While contemporary creation must base itself on previous efforts, it must take as its beginning that point where everything that has already been done ends. Tradition is the raw material, that must be used for construction, which means that it must be transformed into what it has never been. The further we go, the more faithful we are to tradition"28. Thus, tradition played an extremely important role in creating the idiom of modernity and contemporary art, but as a starting point, as a base. The masterpieces of old art were to be treated as a source of inspiration, and even as material, but never as a ready-made scheme for reproduction.

When the New Art Exhibition was held in Vilnius in 1923, the idiom of the "Vilnius artistic tradition" was already widespread, and the strong position of WTAP - unquestionable not only in Vilnius. The avant-garde proposal of "New Art" was judged from the position of superiority - misunderstood, rejected and mocked. The Vilnius press printed reviews of the

27 Thomas Stearns Eliot, "Tradition and the Individual Talent", in: The Egoist, 4, 1919, pp. 54-55 (Part I); 5, 1919 (Parts II-III).

28 Władysław Strzemiński, "B=2", in: Blok, No. 8-9, 1924, p. 20 (in the translation from Vision and Unity), in: Between Worlds: A Sourcebook of Central European Avant-Gardes, 19101930, Eds. Timothy O. Benson and Éva Forgács, Los Angeles County Museum of Art, Cambridge, Massachusetts and London: The MIT Press, 2002, p. 498. 
exhibition, one of them - very mocking - is signed with the initials S.H., under which Stanisław Hermanowicz, associated with WTAP, was hiding; in the future - together with Piotr Hermanowicz - even a co-initiator of reactivation of the Professional Drawing Courses for Craftsmen and their lecturer. He commented ironically and contemptuously, not referring to specific exhibited works: "Every connoisseur of creativity can see several works of 'New Art' at the exhibition, but as a result of the fact that until now science has not been able to mark the border... where the genius of creativity ends, and where the immensity of madness begins and... the current exhibition of 'New Art' contains pictures that confirm the tragedy of artistic conceitedness" ${ }^{\prime 29}$. The critic did not explain neither what this tragedy was supposed to be about, nor what "conceitedness" manifested itself in.

The opening of the New Art Exhibition, which took place on 20 May 1923, was even visited by Ferdynand Ruszczyc himself. He referred to the exhibition as an exhibition of suprematists, he commented in his diary: "One has to see it in order not to understand"

The artistic proposal of the participants of the New Art Exhibition was often met with misunderstanding. It was perceived as an import from Soviet Russia, which was not entirely true. Vytautas Kairiūkštis and Władysław Strzemiński were resettled from Soviet Russia to Vilnius. At the New Art Exhibition, Vilnius was already represented by Vilnius, which was announced in the exhibition catalogue; other artists represented Warsaw (Karol Kryński, Henryk Stażewski, Mieczysław Szczuka, Teresa Żarnowerówna) and Vilnius (Kairiūkštis, Strzemiński). The exhibition shows inspirations from both the Russian avant-garde (Kairiūkštis, Strzemiński) and Western European art - especially French cubism, to which they explicitly referred, but also futurism and German avant-garde, as well as a sign of dada and constructivism. Stażewski and Kryński were the most French-centric of them, close to purism; Szczuka and Żarnowerówna were already active in Berlin. Of all of them, only Szczuka was fascinated by the Soviet avant-garde from El Lissitzky's circle, but this fascination cannot be seen in the works shown at the Vilnius exhibition. Szczuka's contribution to the exhibition was very reserved in the form of "Self-Portrait".

29 [Stanisław Hermanowicz] St. H., "Wystawa 'Sztuki Nowej”, in: Express Wileński, No. 64 (8 VI), 1923, p. 4.

30 Ferdynand Ruszczyc, Dziennik, t. 2.: W Wilnie 1919-1932, Warszawa: Secesja, 1996, pp. 240-241. 
Although Strzemiński, like Kairiūkštis, was previously one of the co-founders of the avant-garde in revolutionary Russia, he had been cutting himself off from Soviet art at the time - openly, even ostentatiously - since 1922. He had already critically summarised contemporary Soviet art in Notatki o sztuce rosyjskiej (Notes on Russian art), which he managed to publish in the Kracow avant-garde magazine Zwrotnica. The article contains an extensive analysis of the "sins" of the Soviet avant-garde, except for Malevich ${ }^{31}$. Strzemiński's text had an overtly anti-Bolshevik slant. Ferdinand Ruszczyc also noted the hostility to Soviet Russia declared by Strzemiński in his diary on 14 August $1922^{32}$.

The art of the avant-garde turned out to be too innovative and thus incomprehensible for other Vilnius artists, so it was ridiculed and gained the Bolshevik label. Let us recall that a significant number of WTAP members also studied in Russia, which was "tactfully forgotten".

In post-war Vilnius, there are three different versions of modernity in art: 1. a latent, yet very effective, long-range formula of visual (and verbal) propaganda, largely of German origin, from the time of the Great War (Bułhak, Ruszczyc and other professors of the Faculty of Fine Arts of Stephen Báthory University); 2. assimilated St. Petersburg classicism from the same period, evolving in the collective consciousness towards the "Vilnius school" and implied historicism, and 3. strictly avant-garde, universal, because it draws on both Western and Russian sources, but rejected locally as too modern and radical, with its imputed stigma of artistic bolshevism (whatever that might mean), although Strzemiński firmly cuts himself off from Soviet art of the time, strongly criticising its creators. The First New Art Exhibition in Vilnius was the first and, at the same time, the last such clear manifestation of avant-garde modernity in Vilnius of the 1920s, and even more significantly, it has also clearly referred to tradition. One can see various artistic, historical and ideological contexts of dynamically changing modernism in Vilnius - from historicism, through neoclassicism, to a significant episode of strictly avant-garde art.

\section{Submitted - 26/05/2020}

31 Władysław Strzemiński, "Notatki o sztuce rosyjskiej”, in: Zwrotnica, No. 3, 1922, p. 79-82; No. 4, 1923, pp. 110-114; in English: "Notes on Russian Art”, in the translation by Wanda Kemp-Welch, in: Between Worlds: A Sourcebook of Central European Avant-Gardes, 1910-1930, Eds. Timothy O. Benson and Éva Forgács, Los Angeles County Museum of Art, Cambridge, Massachusetts and London: The MIT Press, 2002, pp. 272-280.

32 Ferdynand Ruszczyc, op. cit., p. 198. 


\section{Bibliography}

Andriulytė Algè, Ferdynandas Ruszczycas: Civis Vilnensis Sum, Vilnius: Vilniaus dailès akademijos leidykla, 2018.

Bułhak Jan, „Daty biograficzne dotyczące życia i działalności Ferdynanda Ruszczyca", in: Ferdynand Ruszczyc. Życie i dzieło. Ksiega zbiorowa, kom red. Jan Bułhak et al., Wilno: Skład Główny Księgarni św. Wojciecha, 1939.

Bułhak Jan, Dlaczego Ruszczyc „przestat malować". Wspomnienia pośmiertne z portretem artysty, Wilno: St. Turski, 1936.

Eliot Thomas Stearns, "Tradition and the Individual Talent”, in: The Egoist, 4, 1919, pp. 54-55 (Part I); 5, 1919 (Parts II-III).

Ferdynand Ruszczyc. Życie i dzieto. Ksiega zbiorowa, kom. red. Jan Bułhak et al., Wilno: Skład Główny Księgarni św. Wojciecha, 1939.

[Hermanowicz Stanisław] St. H., "Wystawa 'Sztuki Nowej”, in: Express Wileński, No. 64, 1923, p. 4.

Hobsbawm Eric, "Mass Producting Traditions: Europe, 1870-1914”, in: Eric Hobsbawm, Terence Ranger, The Invention of Tradition, Cambridge: Cambridge University Press, 1996, pp. 263-307.

Hobsbawm Eric, Ranger Terence, The Invention of Tradition, Cambridge: Cambridge University Press, 1996.

Gierowska-Kałłaur Joanna, "The Case of Vilnius. The Case of Klaipeda. Excerpts from Polish/Lithuanian Relations", in: Saint-Petersburg Historical Journal, No. 2, 2016, pp. 52-65.

Konstantynów Dariusz, Wileńskie Towarzystwo Artystów Plastyków 1920-1939, Warszawa: Instytut Sztuki Polskiej Akademii Nauk, 2006.

Laučkaitè Laima, “The Heritage of Vilnius in the Eyes of German Art Historians during World War I”, in: R. Born, B. Störtkuhl (Eds.), Apologeten der Vernichtung oder "Kunstschützer"? Kunsthistoriker der Mittelmächte im Ersten
Weltkrieg, Köln Weimar Wien: Böhlau

Verlag, 2017, pp. 141-158.

Laučkaitè Laima, Vilniaus dailè Didžiojo karo metais, Vilnius: Lietuvos kultūros tyrimy institutas; Metai, 2018.

Luba Iwona, Dialog nowoczesności z tradycja w malarstwie polskim dwudziestolecia międzywojennego, Warszawa: Wydawnictwo Neriton, 2004

Luba Iwona, “,From the Impressionist Chaos to the World of Form and Construction' or Vasiliy Shukhaev, Aleksander Yakovlev and their Polish Epigones", in: Vasiliy Shukhaev: Art, Biography, Heritage: A collective monograph, scientific editor E. P. Yakovleva; compilers: E. N. Kamenskaya, E. P. Yakovleva, Moscow: BooksMArt, 2019, pp. 122-139.

Manikowska Ewa, "Mutual Influences Kunstschutz and the Shaping of Polish Art History at the Time of the First World War", in: R. Born, B. Störtkuhl (Eds.), Apologeten der Vernichtung oder "Kunstschützer"? Kunsthistoriker der Mittelmächte im Ersten Weltkrieg, Köln Weimar Wien: Böhlau Verlag, 2017, pp. 83-101.

Manikowska Ewa, Photography and cultural heritage in the age of nationalisms: Europe's Eastern borderlands (1867-1945), London; New York; Oxford; New Delhi; Sydney: Bloomsbury Visual Arts, 2019.

Marciniec Dariusz, "Ministerstwo Sztuki i Kultury Rzeczypospolitej Polskiej w latach 1918-1922”, in: Rocznik Łódzki, No. 63, 2015, p. 95 .

Paleta Wilna, No. 2, 1930, K. Adamska-Roubina (ed.), p. 5.

Podoski Wiktor, "Z Zachęty. Wystawa Jubileuszowa Wileńskiego Towarzystwa Artystów Plastyków”, in: Rzeczpospolita, No. 120, 1920, p. 9 .

Ruszczyc Ferdynand, Dziennik, t. 2.: W Wilnie 1919-1932, Warszawa: Secesja, 1996.

Skoczylas Władysław, “Z wystawy Stowarzyszenia Wileńskich Artystów Plastyków. Sleńdziński”, in: Tygodnik Ilustrowany, No. 46,1922 , p. 737.
$98-2020$

Acta Academiae Artium Vilnensis 
Stażewski Henryk, "Nowa sztuka a spuścizna sztuki epok minionych”, in: Pion, No. 5, 1933, p. 4.

Strzemiński Władysław, "B=2", in: Blok \& Kurier Bloku, No. 8-9, 1924, pp. 18-20.

Strzemiński Władysław, " $\mathrm{B}=2$ " (in the translation from Vision and Unity), in: Between Worlds: A Sourcebook of Central European Avant-Gardes, 1910-1930, Eds. Timothy O. Benson and Éva Forgács, Los Angeles County Museum of Art, Cambridge, Massachusetts and London: The MIT Press, 2002, pp. 497-502.

Strzemiński Władysław, "Notes on Russian Art" (in the translation by Wanda KempWelch), in: Between Worlds: A Sourcebook of Central European Avant-Gardes, 1910-1930, Eds. Timothy O. Benson and Éva Forgács, Los Angeles County Museum of Art, Cambridge, Massachusetts and London: The MIT Press, 2002, pp. 272-280.

Strzemiński Władysław, "O sztuce rosyjskiej. Notatki”, in: Zwrotnica, No. 3, 1922 , pp. 79-82; No. 4, 1923, pp. 110-114.

Strzemiński Władysław, "Wystawa Nowej Sztuki w Wilnie”, in: Zwrotnica, No. 6, 1923, p. 193.

Tatarkiewicz Władysław, "O Wileńskiej Szkole Malarstwa”, in: Potudnie, No. 1, 1921, pp. 3-18.

Weber Paul, Wilna. Eine vergessene Kunststätte, München: R. Piper, 1917.

Wileńskie Towarzystwo Artystów Plastyków 1920-1930, Wilno: s. n., 1930.

Wilno. Przewodnik krajoznawczy Juliusza Kłosa, Prof. Uniwersytetu St. Batorego, Wilno: Wydawnictwo Oddziału Wileńskiego Polsk. Tow. Krajoznawczego, 1923.

Wilno i ziemia wileńska: zarys monograficzny, t. 1, Stanisław Kościałkowski ed., Ferdynad Ruszczyc ill., Wilno: Wojewódzki Komitet Regjonalny, 1930.

Wilno z przed stu lat w akwarelach Franciszka Smuglewicza, [Zdobił książkę Ferdynand Ruszczyc], Wilno: Księgarnia L. Zawadzkiego, 1912. 


\section{Santrauka}

\section{Modernizmo šaltiniai ir kontekstai Vilniaus tarpukario dailèje}

Iwona Luba

Reikšminiai žodžiai: Vilniaus modernizmas, Vilniaus dailininkų draugija, Stepono Batoro universiteto Dailiujų menų fakultetas, Pirmoji naujojo meno paroda Vilniuje, istoricizmas, avangardas.

Straipsnyje bandoma apibrèžti „Vilniaus modernizmo“ sąvoką ir jos ankstyviausias apraiškas ịvairiose, net prieštaringose formuluotėse. Identifikuojami moderniojo meno pokario Vilniuje šaltiniai ir meniniai, istoriniai bei ideologiniai Vilniaus modernizmo kaip dinamiškai kintančio fenomeno kontekstai - nuo vèlyvojo simbolizmo ir neoklasicizmo iki grynai avangardinio meno. Tyrime atsižvelgiama ị originalius teoretinius pareiškimus / manifestus, meno kūrinius bei jų tuometines interpretacijas.

Pokario Vilniuje vyravo trys skirtingos moderniojo meno versijos: 1) kaip latentinè, tačiau itin efektyvi visaapimanti vizualinės (ir verbalinès) propagandos formuluotè, susiformavusi Vokietijoje po Pirmojo pasaulinio karo (Janas Bułhakas, Ferdynandas Ruszczycas ir kiti Stepono Batoro universiteto Dailès fakulteto profesoriai); 2) kaip asimiliuotas to paties periodo Sankt Peterburgo klasicizmas kolektyvinėje sąmonėje, išsivystęs i „Vilniaus mokyklą“ ir atitinkamą istoricizmą; 3) kaip grynai avangardinis ir universalus reiškinys, kadangi rėmėsi tiek Vakarų, tiek Rusijos šaltiniais. Pastaroji traktuotė buvo atmesta lokaliai kaip pernelyg radikali - jai buvo primetama „meninio bolševizmo“ (kad ir ką tai turèjo reikšti) stigma, nors Władysławas Strzemińskis griežtai atsiribojo nuo to meto sovietinio meno ir aršiai kritikavo jo kūrèjus. Pirmoji Naujojo meno paroda Vilniuje buvo pirma ir tuo pačiu paskutinė avangardiškos modernybės apraiška 3 deš. Vilniuje. Svarbu pabrèžti, kad joje buvo labai aiški nuoroda ị tradiciją. Joje galima buvo aptikti ịvairių meninių, istorinių ir ideologinių dinamiškai besikeičiančio Vilniaus modernizmo kontekstų - nuo istoricizmo ir neoklasicizmo iki svarbaus avangardinio meno epizodo.

$98-2020$

Acta Academiae Artium Vilnensis 